Available online on 15.04.2020 at http://jddtonline.info
Open Access to Pharmaceutical and Medical Research
unrestricted non-commercial use, provided the original work is properly cited

Open@Access

Research Article

\title{
Allelopathic effect of leaf extracts of Punica granatum and Spiraea prunifolia against post-harvest rot of tomato and brinjal
}

\author{
Jahangir Abdullah Koka, ${ }^{*}$ Mohd Yaqub Bhat and Abdul Hamid Wani \\ Section of Plant Pathology and Mycology, Department of Botany, University of Kashmir, Hazratbal, Srinagar, India
}

\begin{abstract}
Antimycotic activities of different solvent extracts of Punica granatum L. and Spiraea prunifolia Siebold and Zucc. were carried out through agar well diffusion assay at three concentrations $(25 \mu \mathrm{l}, 50 \mu \mathrm{l}$ and $75 \mu \mathrm{l})$ against seven fungi causing rot diseases of tomato and brinjal. All the concentration of plant extracts showed antifungal activity against tested pathogenic fungi. Antimycotic activity increased with the increased concentrations of plant extracts. However, higher concentrations proved more effective than lower concentrations. It was reve aled from the present study that the ethanolic extract of Punica granatum L. showed maximum antifungal activity against Rhizoctonia solani and Penicillium expansum and least inhibitory activity against Aspergillus niger. However, the aqueous extract of Punica granatum L. showed maximum antimycotic activity against Rhizoctonia solani and Alternaria alternata and least inhibitory effect against Penicillium expansum. It was further observed from the present study that the ethanolic extract of Spiraea prunifolia Siebold and Zucc. showed maximum antimycotic activity against Rhizoctonia solani and least inhibitory effect against Alternaria alternata. Whereas the aqueous extract of Spiraea prunifolia Siebold and Zucc showed maximum antifungal activity against Aspergillus niger and least inhibitory activity against Alternaria alternata.
\end{abstract}

Keywords: Plant extracts, Concentration, Antimycotic effectiveness, tomato and brinjal, fungal rot pathogens, Inhibition zone.

Article Info: Received 29 Jan 2020; $\quad$ Review Completed 12 March 2020; Accepted 19 March 2020; Available online 15 April 2020

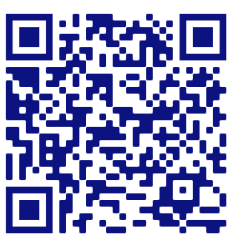

Cite this article as:

Koka JA, Bhat MY, Wani AH, Allelopathic effect of leaf extracts of Punica granatum and Spiraea prunifolia against post harvest rot of tomato and brinjal, Journal of Drug Delivery and Therapeutics. 2020; 10(2-s):1-6

http://dx.doi.org/10.22270/jddt.v10i2-s.3948

Jahangir Abdullah Koka, , Section of Plant Pathology and Mycology, Department of Botany, University of Kashmir, Hazratbal, Srinagar, India

\section{INTRODUCTION}

Vegetables are attacked by several pathogens causing many fruit rot diseases under storage and on standing crop conditions ${ }^{1,2}$. Among all diseases of vegetables, postharvest decays of vegetables and fruits account for significant losses. It is estimated that harvested vegetables and fruits are decayed by pathogens during postharvest handling to an extent of 20-25\% even in developed countries 3,4,5. Several control strategies have been employed by agricultural scientists to reduce the losses caused by pathogenic fungi. In this study, the important medicinal plants Punica granatum L. and Spiraea prunifolia Siebold and Zucc. have been evaluated for their antimycotic activity. Punica granatum (Pomegranate) is a small tree, five to eight meters tall and mainly found in Iran, Northern Himalayas of India, China, USA and throughout the Mediterranean region. Many diseases like digestive disorders, urinary infections, arthritis, skin disorders, sore throats, coughs, tapeworm expulsion were treated by natural and holistic medicine, pomegranate as one of the constituent. However, as such the modern research is concerned, pomegranates are used in treatments of skin cancer, prostate cancer, diabetes and osteoarthritis 6,7 .

Considering their medicinal importance, perishable nature and extent of losses caused by fungal rots of tomato and brinjal, the present study was undertaken to check the efficacy of Punica granatum L. and Spiraea prunifolia Siebold and Zucc. against rot causing fungi.

\section{MATERIALS AND METHODS}

\subsection{Plant collection and identification}

Fresh samples of local medicinal plants Punica granatum and Spiraea prunifolia were collected from Kashmir valley and identified at Kashmir University Herbarium (KASH), Centre of Plant Taxonomy, Department of Botany, University of Kashmir, Srinagar. Adequate amount of the leaves of these plants were collected in polythene bags, brought to laboratory for evaluating their antimycotic activity under in vitro conditions. 


\subsection{Preparation of plant extracts}

These plant leaves in a required quantity were sundried for 24 hours and then milled into powder using morter and pestle. About $20 \mathrm{~g}$ of coarsely powdered leaves $(20 \mathrm{~g} / 100 \mathrm{~mL})$ were extracted with ethanol and water separately in order to extract non-polar and polar compounds in a soxhlet extractor for 8 to 10 hours (30$\left.50^{\circ} \mathrm{C}\right)^{8}$.

\subsection{Preparation of inoculums of fungi}

The fungal test organisms, viz, Penicillium expansum, Mucor plumbeus, Alternaria alternata, Aspergillus niger, Trichothecium roseum Penicillium chrysogenum, and Rhizoctonia solani used in present study were isolated and identified from rotten fruits. The tested strains are stored at section of Mycology and Plant Pathology, Department of Botany University of Kashmir. Fungal spores were collected from these cultures after 7 days and density of spore suspension was adjusted to $2 \times 10^{5}$ (CFU/mL) spores 9,10.

\subsection{Antifungal activity}

The antifungal activity of the plant extracts were determined by agar well diffusion method as adopted by 11,12,13. Seven day old fungal cultures grown on PDA medium were used to assess the antifungal activity of selected plant extracts. An aliquot of $100 \mu \mathrm{l}$ inoculum from each fungal species was inoculated in $20 \mathrm{ml}$ of molten SDA medium in culture tubes. The culture tubes were then homogenised manually and poured into $90 \mathrm{~mm}$ Petri plate. The culture plates were allowed to solidify inside the laminar airflow chamber and three wells at periphery of each Petri plate were made using sterile cork borers of $5 \mathrm{~mm}$ in diameter. A $2 \mathrm{mg} / \mathrm{ml}$ stock solution was made from the plant extract and then different volumes $(25 \mu \mathrm{l}, 50 \mu \mathrm{l}$ and $75 \mu \mathrm{l})$ from that stock solution were loaded to respective wells. Hexaconazole solution $(20 \mu \mathrm{l} /$ well) was used as control in the separate well in the same petri plate. The effect of plant extracts on different rot causing fungi were evaluated and the plates were then sealed and incubated at $25 \pm 2{ }^{\circ} \mathrm{C}$ for $4-5$ days. Three replicates were made for each treatment. Antifungal potential was calculated by measuring inhibition zone diameters in millimeters ( $\mathrm{mm}$ ) with the help of standard measuring scale 14 .

\subsection{Statistical analysis}

The data collected during these investigations were subjected to appropriate statistical analysis using SPSS statistical software (version 16.0). The data was statistically analyzed by one way analysis of variance (ANOVA) and comparison of the means was done by Duncan multiple comparison tests at $\mathrm{P} \leq 0.05$.Standard deviation was calculated as $\delta=\sqrt{\frac{\sum x^{2}}{N-1}}$.

\section{RESULTS}

3.1. Effect of leaf extracts of Punica granatum $L$ on the zone of mycelial inhibition of some rot causing fungi.

It was observed from results (Table 1, Fig 1) that the ethanolic extract of Punica granatum L. showed maximum mycelial inhibition against Rhizoctonia solani and Penicillium expansum at $25 \mu \mathrm{l}, 50 \mu \mathrm{l}$ and $75 \mu \mathrm{l}$ concentrations $(2 \mathrm{mg} / \mathrm{ml}$, $5 \mathrm{mg} / \mathrm{ml}$ and $7 \mathrm{mg} / \mathrm{ml}$ ) with zone of inhibition of $23.33 \mathrm{~mm}$, $25.00 \mathrm{~mm}, 27.33 \mathrm{~mm}$ and $21.00 \mathrm{~mm}, 24.00 \mathrm{~mm}, 27.00 \mathrm{~mm}$ respectively. Whereas moderate inhibitory fungal activity was shown against Mucor plumbeus and Alternaria alternata with zone of inhibition as $19.33 \mathrm{~mm}, 26.00 \mathrm{~mm}, 26.33 \mathrm{~mm}$ and $19.33 \mathrm{~mm}, 22.33 \mathrm{~mm}, 26.00 \mathrm{~mm}$ respectively. The zone of inhibition of mycelial growth of Trichothecium roseum and Penicillium chrysogenum was $18.00 \mathrm{~mm}, 21.33 \mathrm{~mm}, 23.66$ $\mathrm{mm}$ and $16.33 \mathrm{~mm}, 19.66 \mathrm{~mm}, 23.00 \mathrm{~mm}$ by leaf extracts of $P$. granatum L respectively. The zone of inhibition of mycelial growth of Aspergillus niger was least with zone of inhibition as $16.33 \mathrm{~mm}, 18.33 \mathrm{~mm}$ and $20.66 \mathrm{~mm}$ at $25 \mu \mathrm{l}, 50 \mu \mathrm{l}$ and 75 $\mu \mathrm{l}$ concentrations of leaf extracts respectively.

It was also revealed from results (Table 2, Fig. 2) that the aqueous leaf extract of Punica granatum L. caused maximum inhibition in mycelial growth at $25 \mu \mathrm{l}, 50 \mu \mathrm{l}$ and $75 \mu \mathrm{l}$ concentrations with zone of inhibition of $20.33 \mathrm{~mm}, 22.33$ $\mathrm{mm}, 24.00 \mathrm{~mm}$ and $17.66 \mathrm{~mm}, 20.33 \mathrm{~mm}, 24.33 \mathrm{~mm}$ against Rhizoctonia solani and Alternaria alternata respectively. Moderate antifungal activity was recorded against Mucor plumbeus and Trichothecium roseum with zone of inhibition of $17.33 \mathrm{~mm}, 20.00 \mathrm{~mm}, 23.33 \mathrm{~mm}$ and $16.00 \mathrm{~mm}, 19.00 \mathrm{~mm}$, $21.33 \mathrm{~mm}$ due to aqueous leaf extract of $P$. granatum L. respectively. The zone of inhibition in mycelial growth of Aspergillus niger and Penicillium chrysogenum was 14.66 $\mathrm{mm}, 16.00 \mathrm{~mm}, 18.66 \mathrm{~mm}$ and $13.00 \mathrm{~mm}, 15.66 \mathrm{~mm}, 21.00$ $\mathrm{mm}$ by leaf extracts of $P$. granatum respectively. The zone of inhibition in mycelial growth of Penicillium expansum was least with zone of inhibition of $12.33 \mathrm{~mm}, 14.33 \mathrm{~mm}$ and $17.66 \mathrm{~mm}$ at $25 \mu \mathrm{l}, 50 \mu \mathrm{l}$ and $75 \mu \mathrm{l}$ concentrations of aqueous leaf extracts of $P$. granatum respectively.

Table 1 Effect of ethanolic leaf extracts of Punica granatum L. at different concentration on the zone of mycelial inhibition of some rot causing fungi.

\begin{tabular}{|c|c|c|c|c|}
\hline \multirow{2}{*}{$\begin{array}{l}\text { Fungal } \\
\text { Pathogens }\end{array}$} & \multicolumn{4}{|c|}{ Zone of mycelial Inhibition (mm) } \\
\hline & $25 \mu \mathrm{l}$ & $50 \mu \mathrm{l}$ & $75 \mu \mathrm{l}$ & Control \\
\hline Penicillium expansum & $21.00 \pm 1.00^{\mathrm{d}}$ & $24.00 \pm 1.00^{c}$ & $27.00 \pm 1.00^{\mathrm{b}}$ & $31.33 \pm 0.57 \mathrm{a}$ \\
\hline Aspergillus niger & $16.33 \pm 0.57 \mathrm{~d}$ & $18.33 \pm 0.57 c$ & $20.66 \pm 0.57 \mathrm{~b}$ & $22.66 \pm 0.57 \mathrm{a}$ \\
\hline Alternaria alternate & $19.33 \pm 0.57 \mathrm{~d}$ & $22.33 \pm 0.57 c$ & $26.00 \pm 1.00^{\mathrm{b}}$ & $29.33 \pm 0.57 a$ \\
\hline Mucor plumbeus & $19.33 \pm 0.57 c$ & $26.00 \pm 0.57^{b}$ & $26.33 \pm 1.52^{a}$ & $27.33 \pm 0.57 \mathrm{a}$ \\
\hline Penicillium chrysogenum & $16.33 \pm 0.57 \mathrm{~d}$ & $19.66 \pm 0.57 c$ & $23.00 \pm 1.00^{\mathrm{b}}$ & $26.33 \pm 0.57 a$ \\
\hline Trichothecium roseum & $18.00 \pm 1.00^{\mathrm{d}}$ & $21.33 \pm 0.57 c$ & $23.66 \pm 0.57 \mathrm{~b}$ & $25.66 \pm 0.57 a$ \\
\hline Rhizoctonia solani & $23.33 \pm 0.57 \mathrm{~d}$ & $25.00 \pm 1.00^{c}$ & $27.33 \pm 0.57 \mathrm{~b}$ & $29.33 \pm 0.57 \mathrm{a}$ \\
\hline
\end{tabular}

Each value is mean of 3 replicates \pm SD

Mean values followed by different superscript in a column are significantly different $(p \leq 0.05)$ 


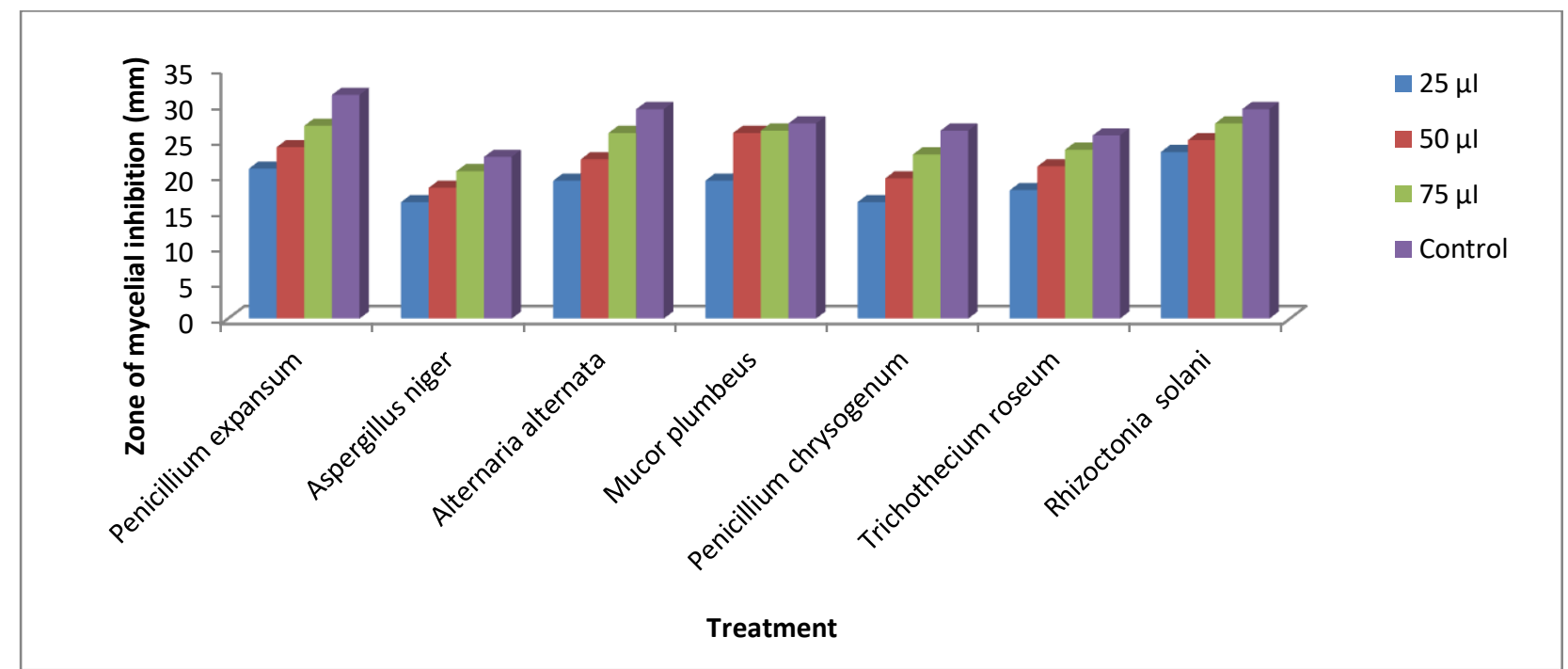

Fig 1. Effect of ethanolic leaf extracts of Punica granatum L. at different concentrations on the zone of mycelial inhibition of some rot causing fungi.

Table 2 Effect of aqueous leaf extracts of Punica granatum L. at different concentrations on the zone of mycelial inhibition of some rot causing fungi.

\begin{tabular}{|l|c|c|c|c|}
\hline \multirow{2}{*}{$\begin{array}{l}\text { Fungal } \\
\text { Pathogens }\end{array}$} & \multicolumn{3}{|c|}{ Zone of mycelial Inhibition (mm) } \\
\cline { 2 - 5 } & $\mathbf{2 5} \boldsymbol{\mu l}$ & $\mathbf{5 0} \boldsymbol{\mu l}$ & $\mathbf{7 5} \boldsymbol{\mu l}$ & Control \\
\hline Penicillium expansum & & & $17.66 \pm 1.00^{\mathrm{b}}$ & $25.00 \pm 1.00^{\mathrm{a}}$ \\
\hline Aspergillus niger & $12.33 \pm 0.57^{\mathrm{d}}$ & $14.33 \pm 0.57^{\mathrm{c}}$ & $18.66 \pm 0.57^{\mathrm{a}}$ & $19.33 \pm 0.57^{\mathrm{a}}$ \\
\hline Alternaria alternata & $14.66 \pm 0.57^{\mathrm{c}}$ & $16.00 \pm 1.00^{\mathrm{b}}$ & $27.33 \pm 0.57^{\mathrm{a}}$ \\
\hline Mucor plumbeus & $17.66 \pm 0.57^{\mathrm{d}}$ & $20.33 \pm 0.57^{\mathrm{c}}$ & $24.33 \pm 0.57^{\mathrm{b}}$ & $26.66 \pm 0.57^{\mathrm{a}}$ \\
\hline Penicillium chrysogenum & $17.33 \pm 0.57^{\mathrm{d}}$ & $20.00 \pm 1.00^{\mathrm{c}}$ & $23.33 \pm 1.52^{\mathrm{b}}$ & $24.33 \pm 0.57^{\mathrm{a}}$ \\
\hline Trichothecium roseum & $13.00 \pm 1.00^{\mathrm{d}}$ & $15.66 \pm 0.57^{\mathrm{c}}$ & $21.00 \pm 1.00^{\mathrm{b}}$ & $23.33 \pm 0.57^{\mathrm{a}}$ \\
\hline Rhizoctonia solani & $16.00 \pm 1.00^{\mathrm{d}}$ & $19.00 \pm 1.00^{\mathrm{c}}$ & $21.33 \pm 0.57^{\mathrm{b}}$ & $26.33 \pm 0.57^{\mathrm{a}}$ \\
\hline
\end{tabular}

Each value is mean of 3 replicates \pm SD

Mean values followed by different superscript in a column are significantly different $(\mathrm{p} \leq 0.05)$

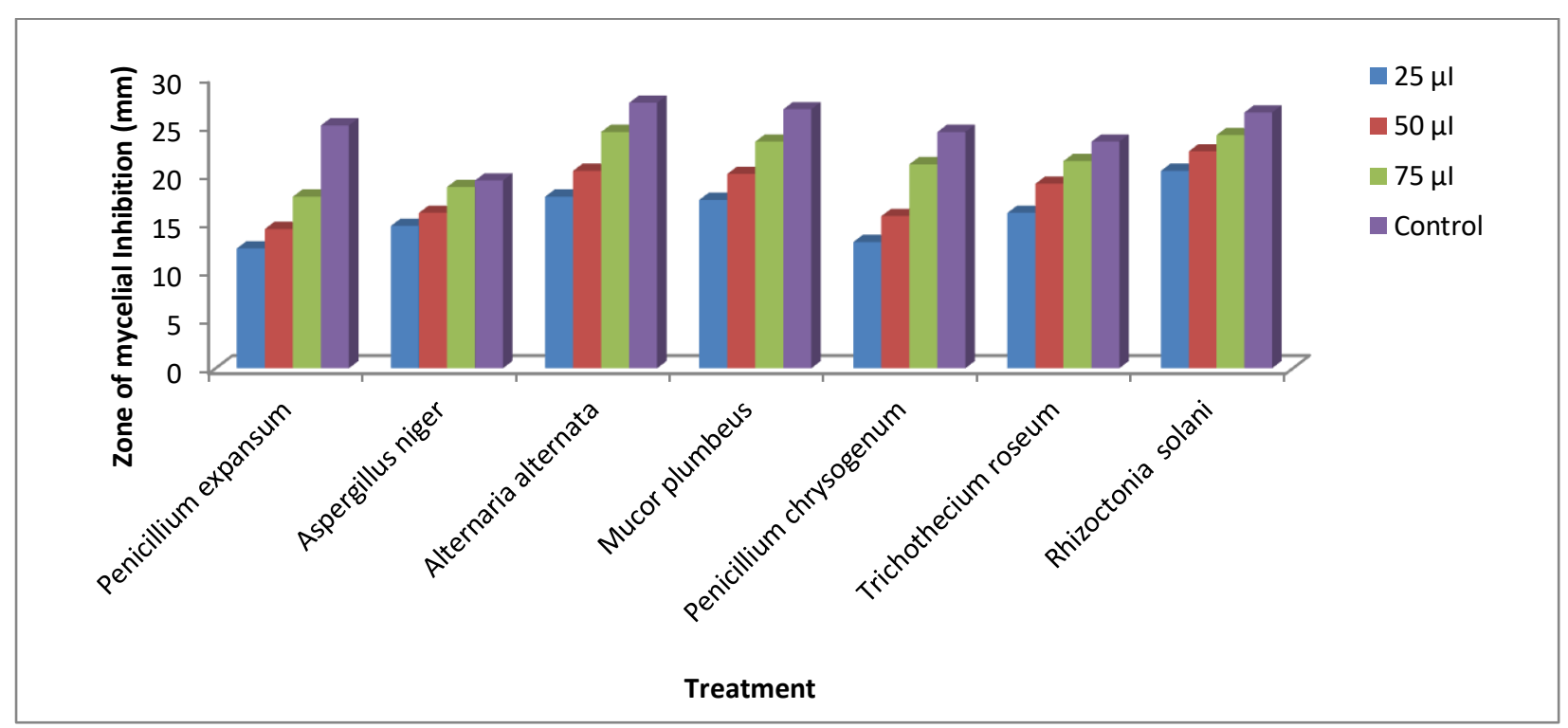

Fig 2 Effect of aqueous leaf extracts of Punica granatum L. at different concentrations on the zone of mycelial inhibition of some rot causing fungi. 
3.2. Effect of leaf extracts of Spiraea prunifolia Siebold and Zucc. on the zone of mycelial inhibition of some rot causing fungi.

It was observed from results (Table 3, Fig. 3) that the ethanolic leaf extract of Spiraea prunifolia Siebold and Zucc. showed maximum inhibitory activity on mycelial growth at $25 \mu \mathrm{l}, 50 \mu \mathrm{l}$ and $75 \mu \mathrm{l}$ concentrations with zone of inhibition of $20.00 \mathrm{~mm}, 20.66 \mathrm{~mm}$ and $23.00 \mathrm{~mm}$ against Rhizoctonia solani respectively. Whereas least inhibitory activity was shown against Alternaria alternata with zone of mycelial inhibition of $12.33 \mathrm{~mm}, 14.66 \mathrm{~mm}$ and $17.33 \mathrm{~mm}$ at $25 \mu \mathrm{l}, 50$ $\mu \mathrm{l}$ and $75 \mu \mathrm{l}$ concentrations respectively. The moderate inhibition in mycelial growth was observed in ethanolic leaf extract at different concentrations against Penicillium chrysogenum with zone of inhibition of $19.00 \mathrm{~mm}, 21.00 \mathrm{~mm}$ and $23.33 \mathrm{~mm}$ and against Aspergillus niger with zone of inhibition of $18.00 \mathrm{~mm}, 20.00 \mathrm{~mm}$ and $22.33 \mathrm{~mm}$ at $25 \mu \mathrm{l}, 50$ $\mu \mathrm{l}$ and $75 \mu \mathrm{l}$ concentrations of ethanolic leaf extracts respectively. The inhibition in mycelial growth of Mucor plumbeus and Trichothecium roseum was $16.33 \mathrm{~mm}, 19.00$ $\mathrm{mm}, 21.00 \mathrm{~mm}$ and $14.00 \mathrm{~mm}, 16.00 \mathrm{~mm}, 18.00 \mathrm{~mm}$ at $25 \mu \mathrm{l}$, $50 \mu \mathrm{l}$ and $75 \mu \mathrm{l}$ concentration of ethanolic leaf extracts of $S$. prunifolia respectively. However, the ethanolic extract of Spiraea prunifolia showed antifungal activity against
Penicillium expansum with zone of mycelial inhibition of $13.00 \mathrm{~mm}, 15.00 \mathrm{~mm}$ and $17.00 \mathrm{~mm}$ at $25 \mu \mathrm{l}, 50 \mu \mathrm{l}$ and $75 \mu \mathrm{l}$ concentrations respectively.

Similarly, it was found from results (Table 4, Fig. 4) that the aqueous extract of Spiraea prunifolia Siebold and Zucc. showed maximum inhibitory activity in mycelial inhibition against Aspergillus niger at $25 \mu \mathrm{l}, 50 \mu \mathrm{l}$ and $75 \mu \mathrm{l}$ concentrations with zone of inhibition of $16.00 \mathrm{~mm}, 18.00$ $\mathrm{mm}$ and $20.00 \mathrm{~mm}$ respectively. Moderate inhibition in mycelial growth was found in aqueous plant extracts against Penicillium chrysogenum, Mucor plumbeus and Rhizoctonia solani with zone of inhibition of $14.33 \mathrm{~mm}, 17.00 \mathrm{~mm}, 20.00$ mm., $14.00 \mathrm{~mm}, 16.66 \mathrm{~mm}, 20.00 \mathrm{~mm}$ and $14.00 \mathrm{~mm}, 16.33$ $\mathrm{mm}, 20.00 \mathrm{~mm}$ at $25 \mu \mathrm{l}, 50 \mu \mathrm{l}$ and $75 \mu \mathrm{l}$ concentrations respectively. The zone of inhibition of mycelial growth of Trichothecium roseum and Penicillium expansum was 11.00 $\mathrm{mm}, 13.33 \mathrm{~mm}, 16.00 \mathrm{~mm}$ and $10.33 \mathrm{~mm}, 12.33 \mathrm{~mm}, 14.00$ $\mathrm{mm}$ at $25 \mu \mathrm{l}, 50 \mu \mathrm{l}$ and $75 \mu \mathrm{l}$ concentrations of aqueous extract of $S$. prunifolia respectively. The least mycelial inhibition was found against Alternaria alternata with zone of inhibition as $10.00 \mathrm{~mm}, 11.66 \mathrm{~mm}$ and $15.00 \mathrm{~mm}$ at $25 \mu \mathrm{l}$, $50 \mu \mathrm{l}$ and $75 \mu \mathrm{l}$ concentrations of aqueous leaf extracts of $S$. prunifolia respectively.

Table 3 Effect of ethanolic leaf extracts of Spiraea prunifolia Siebold and Zucc. at different concentrations on the zone of mycelial inhibition of some rot causing fungi.

\begin{tabular}{|l|c|c|c|c|}
\hline \multirow{2}{*}{$\begin{array}{l}\text { Fungal } \\
\text { Pathogens }\end{array}$} & \multicolumn{3}{|c|}{ Zone of mycelial Inhibition (mm) } \\
\cline { 2 - 5 } & $\mathbf{2 5} \boldsymbol{\mu l}$ & $\mathbf{5 0} \boldsymbol{\mu l}$ & $\mathbf{7 5} \boldsymbol{\mu l}$ & \multicolumn{1}{c|}{ Control } \\
\hline Penicillium expansum & $13.00 \pm 1.00^{\mathrm{d}}$ & $15.00 \pm 1.00^{\mathrm{c}}$ & $17.00 \pm 1.00^{\mathrm{b}}$ & $19.66 \pm 0.57^{\mathrm{a}}$ \\
\hline Aspergillus niger & $18.00 \pm 1.00^{\mathrm{d}}$ & $20.00 \pm 1.00^{\mathrm{c}}$ & $22.33 \pm 0.57^{\mathrm{b}}$ & $25.00 \pm 1.00^{\mathrm{a}}$ \\
\hline Alternaria alternata & $12.33 \pm 0.57^{\mathrm{c}}$ & $14.66 \pm 0.57^{\mathrm{b}}$ & $17.33 \pm 0.57^{\mathrm{a}}$ & $18.00 \pm 1.00^{\mathrm{a}}$ \\
\hline Mucor plumbeus & $16.33 \pm 0.57^{\mathrm{d}}$ & $19.00 \pm 1.00^{\mathrm{c}}$ & $21.00 \pm 1.00^{\mathrm{b}}$ & $25.00 \pm 1.00^{\mathrm{a}}$ \\
\hline Penicillium chrysogenum & $19.00 \pm 1.00^{\mathrm{d}}$ & $21.00 \pm 1.00^{\mathrm{c}}$ & $23.33 \pm 0.57^{\mathrm{b}}$ & $26.33 \pm 0.57^{\mathrm{a}}$ \\
\hline Trichothecium roseum & $14.00 \pm 1.00^{\mathrm{d}}$ & $16.00 \pm 1.00^{\mathrm{c}}$ & $18.00 \pm 1.00^{\mathrm{b}}$ & $24.66 \pm 0.57^{\mathrm{a}}$ \\
\hline Rhizoctonia solani & $20.00 \pm 1.00^{\mathrm{c}}$ & $20.66 \pm 1.52^{\mathrm{c}}$ & $23.00 \pm 1.00^{\mathrm{b}}$ & $25.66 \pm 0.57^{\mathrm{a}}$ \\
\hline
\end{tabular}

Each value is mean of 3 replicates \pm SD

Mean values followed by different superscript in a column are significantly different $(p \leq 0.05)$

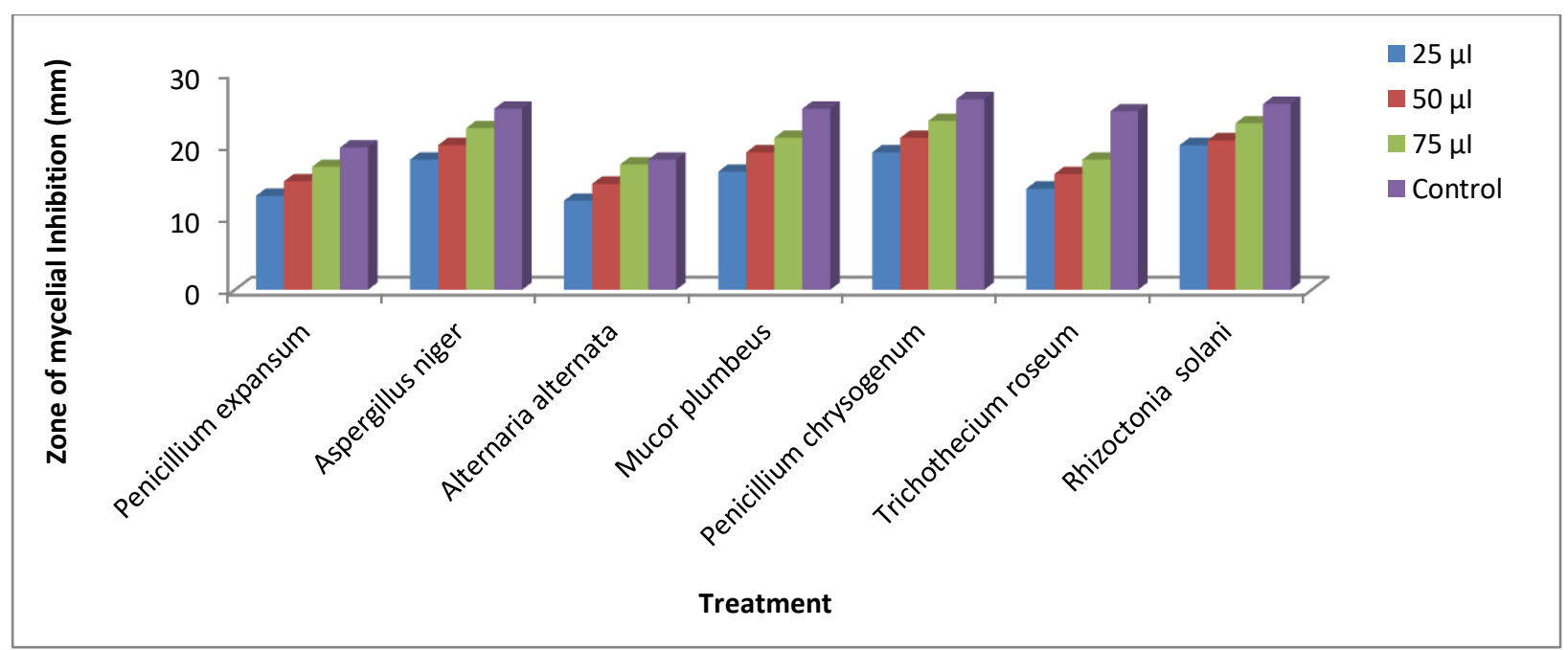

Fig 3 Effect of ethanolic leaf extracts of Spiraea prunifolia Siebold and Zucc. at different concentrations on the zone of mycelial inhibition of some rot causing fungi. 
Table 4 Effect of aqueous leaf extracts of Spiraea prunifolia Siebold and Zucc.at different concentrations on the zone of mycelial inhibition of some rot causing fungi.

\begin{tabular}{|l|c|c|c|c|}
\hline \multirow{4}{*}{$\begin{array}{l}\text { Fungal } \\
\text { Pathogens }\end{array}$} & \multicolumn{4}{|c|}{ Zone of mycelial Inhibition (mm) } \\
\cline { 2 - 5 } & $\mathbf{2 5 \mu l}$ & $\mathbf{5 0} \boldsymbol{\mu l}$ & $\mathbf{7 5} \boldsymbol{\mu l}$ & Control \\
\hline Penicillium expansum & $10.33 \pm 0.57^{\mathrm{d}}$ & $12.33 \pm 0.57^{\mathrm{c}}$ & $14.00 \pm 1.00^{\mathrm{b}}$ & $17.33 \pm 1.00^{\mathrm{a}}$ \\
\hline Aspergillus niger & $16.00 \pm 1.00^{\mathrm{d}}$ & $18.00 \pm 1.00^{\mathrm{c}}$ & $20.00 \pm 1.00^{\mathrm{b}}$ & $22.33 \pm 0.57 \mathrm{a}$ \\
\hline Alternaria alternata & $10.00 \pm 1.00^{\mathrm{c}}$ & $11.66 \pm 1.52^{\mathrm{c}}$ & $15.00 \pm 1.00^{\mathrm{b}}$ & $17.33 \pm 0.57^{\mathrm{a}}$ \\
\hline Mucor plumbeus & $14.00 \pm 1.00^{\mathrm{d}}$ & $16.66 \pm 0.57^{\mathrm{c}}$ & $20.00 \pm 1.00^{\mathrm{b}}$ & $21.66 \pm 0.57^{\mathrm{a}}$ \\
\hline Penicillium chrysogenum & $14.33 \pm 0.57 \mathrm{~d}$ & $17.00 \pm 1.00^{\mathrm{c}}$ & $20.00 \pm 1.00^{\mathrm{b}}$ & $21.66 \pm 0.57 \mathrm{a}$ \\
\hline Trichothecium roseum & $11.00 \pm 1.00^{\mathrm{d}}$ & $13.33 \pm 0.57^{\mathrm{c}}$ & $16.00 \pm 1.00^{\mathrm{b}}$ & $20.33 \pm 0.57^{\mathrm{a}}$ \\
\hline Rhizoctonia solani & $14.00 \pm 1.00^{\mathrm{c}}$ & $16.33 \pm 1.52^{\mathrm{b}}$ & $20.00 \pm 1.00^{\mathrm{a}}$ & $21.33 \pm 0.57^{\mathrm{a}}$ \\
\hline
\end{tabular}

Each value is mean of 3 replicates \pm SD

Mean values followed by different superscript in a column are significantly different $(\mathrm{p} \leq 0.05)$

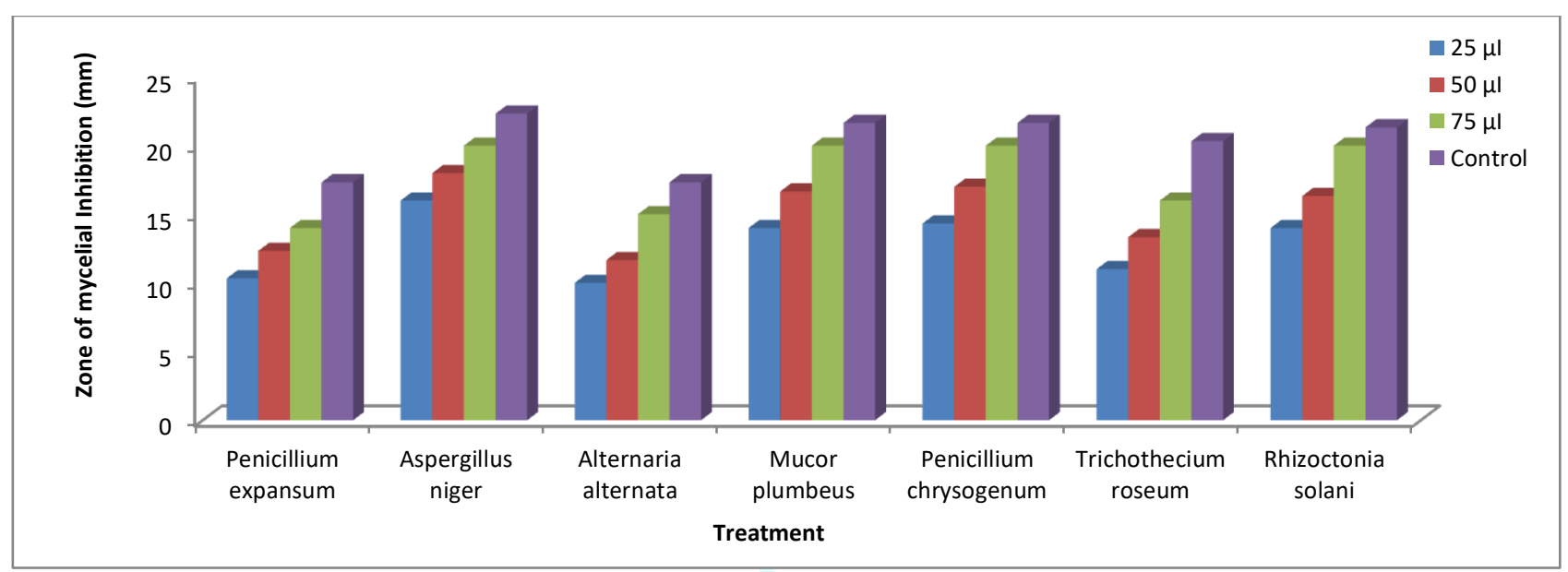

Fig 4 Effect of aqueous leaf extracts of Spiraea prunifolia Siebold and Zucc. at different concentrations on the zone of mycelial inhibition of some rot causing fungi.

\section{DISCUSSION}

The results clearly indicates that extracts of two medicinal plants Punica granatum L. and Spiraea prunifolia Siebold and Zucc. brought about significant inhibition in the mycelial growth at their different concentration. Higher concentration proved effective than lower concentration. In the present study some plant extracts were evaluated for their antifungal activity against the fungus causing rot of tomato and brinjal. These two test plant species proved efficient in reducing the mycelial growth of fungi causing rot diseases of tomato and brinjal fruits. Such study has been carried for the first time on the extracts of Punica granatum L. and Spiraea prunifolia Siebold and Zucc. However, extracts of other plants have been evaluated for their antimycotic activity in a similar way. In a similar study, efficacy of five plant extracts, viz. Artimesia absinthium L., Datura stramonium L., Urtica dioica L., Juglans regia L. and Mentha arvensis L. was studied against Alternaria solani causing disease on potato and found that $D$. stramonium proved effective botanical, followed by $A$. absinthium and least inhibitory effect shown by Urtica dioica. 15. 16 tested different plant parts and found that root extract exhibits more results causing $81-92 \%$ reduction in biomass. Several workers studied the inhibitory effect of different plant extracts against mycelial growth of Collectotrichum graminicola and Rhizopus stolonifer 17,18 19 reported the efficiency of ethanolic extract of $C$. procera latex against Candida albicans. Increase in Calotropis procera extract concentration decreases the mycelia growth, percentage spores germination and germ tube extension in Fusarium oxysporum and Aspergillus carbonaris, whereas growth of
Humicola brevis and Penicillium lanosum were not affected 20. A large diameter of clearance of $C$. albicans than that of other fungal strains was shown due to $C$. gigantea latex extract 21 . Inhibitory effect of plant extract of onion, ginger and other plants on the spore germination and mycelial growth of several pathogenic fungi was studied by different workers as $22,23,24,25$. Leaf extracts of $O$. sanctum was found most effective against $A$. brassicae as compared to other tested extracts ${ }^{26 .} 27$ reported the antimycotic activity of aqueous and alcoholic neem leaf extracts on some fungi, viz. Aspergillus, Rhizopus and reported that the alcoholic extracts of neem leaf was most effective in comparison to aqueous extract for reducing the growth of Rhizopus and Aspergillus. The crude aqueous and alcoholic leaf extracts of neem was more effective in inhibitions of growth of Aspergillus in comparison to inhibitory effects on Rhizopus growth in culture medium. 28 studied the antimycotic activity of various extracts like aqueous, alcoholic and ethyl acetate extracts of leaves of five Terminalia species against five plant pathogenic fungi like $A$. flavus, A. niger, Alternaria brassicicola, A. alternata and Helminthosporium tetramera and found that the ethyl acetate extract showed most inhibitory effect against all the fungi tested. Antimycotic activity of chloroform and methanol leaf extracts against seven fungi viz., Mucor sp., Trichoderma viride, Verticillium lecanii, Candida albicans, Penicillium sp., A. fumigates and A. niger and found that methanol extract showed maximum inhibition in Fusarium sp. ${ }^{29}$. Similarly, other studies also confirmed the effect of different concentration of plant extracts against fungi causing rotting of tomato, brinjal and other fruits $30,31,32,33,34,35$. The antifungal activities of these plant extracts are attributed to 
different chemical compounds like phenols, flavonoids, isoflavonoids, coumarins, pyrones, alkaloids, etc. present in these plants which effect the growth of pathogenic fungi 36 . Hence these plant extracts may have potential as a new natural fungicide for management of fungal rot pathogens. However, further study is needed to explore the possibility of using plant extracts against other pathogenic fungi responsible for causing decaying of fruits and vegetables under storage and on standing plants.

\section{ACKNOWLEDGEMENT}

The authors are highly thankful to the Head, Department of Botany, University of Kashmir, Hazratbal, Srinagar for providing necessary facilities for the smooth research and also to Curator, Centre of Biodiversity and Plant Taxonomy, Department of Botany, University of Kashmir, Hazratbal, Srinagar, J and K in proper identification of the plants.

\section{REFERENCES}

1. Snowdon AL. Postharvest diseases and disorders of fruits and vegetables. Vol.1. General Introduction and fruits. Boca Raton, F.L. CRC Press.1992. pp.302.

2. Naqvi SAMH. Diseases of fruits and vegetables, Kluwer Academic Publishers, Netherland, 2004. 2: 511-535.

3. El-Ghaouth A. Wilson CL. Wisniewski ME. Biologically based alternatives to synthetic fungicides for the postharvest diseases of fruit and vegetables. In: Naqvi, S. A. M. H. (Ed.) Diseases of Fruit and Vegetables, Kluwer Academic Publishers, The Netherlands, 2004. 2: 511-535.

4. Droby S. Improving quality and safety of fresh fruit and vegetables after harvest by the use of biocontrol agents and natural materials. Acta Horticulturae, 2006. 709: 45-51.

5. Singh D. Sharma RR. Postharvest diseases of fruit and vegetables and their management. In: Prasad, D. (Ed.) Sustainable Pest Management. Daya Publishing House, New Delhi, India.2007.

6. Bhowmik D. Gopinath H. Pragati Kumar B. Duraivel S. Aravind G. Sampath Kumar KP. Medicinal uses of Punica granatum and its health benefits. Journal of Pharmacognomy and Phytochemistry, 2013. 1(5):28-35.

7. Facciola S. Cornucopia: a Source Book of Edible Plants Kampong PublicatioCalifornia. (1990) 166

8. Elgorashi EE. Van Staden J. Pharmacological screening of six Amaryllidaceae species. Journal of Ethnopharmacology, 2004. 90:27-32.

9. Broekaert WF. Terras FRG. Cammue BPA. Vanderleyden J. An automated quantative assay for fungal growth inhibition. FEMS Microbiology Letters, 1990. 69:55-60.

10. Abril M. Curry KJ. Smith BJ. Wedge DE. Improved microassays used to test natural product based and conventional fungicides on plant pathogenic fungi. Plant dis. 2008. 92: 106112.

11. Perez C. Pauli M.Bazerque P. An antibiotic assay by the well agar method. Acta Biolog, Med. Experiment.1990; 15:113-115.

12. Alzoreky NS. Nakahara K. Antibacterial activity of extracts from some edible plants commonly consumed in Asia. International Journal of Food Microbiology 2003.80:223-230.

13. Ahmad N. Amir MK. Ayaz S. Ahmad JA. Antimicrobial profile of the selected medicinal plants. Int J Chem Lif. Sci. 2012. 01:1039-1041.

14. Norrel SA. Messley KE. Microbilogy laboratory Manual Principlesw and Applications,Prentice Hall, Upper Saddle River. New Jersey. 1997.85-90.

15. Ganie SA. Ghani MY. Qazi N. Shabir-u-Rehman. Bioefficacy of plant extracts and biocontrol agents against Alternaria solani. African Journal of Microbiology Research, 2013. 7(34): 43974402.

16. Mehmood T. Shafique S. Shafique S. Zaheer Z. Fungitoxic potential of Tagetus erectus for the management of Alternaria alternata strains of tomato. Pak. J. Bot. 2014. 46(3): 10471054.

17. Akpa AD. Musa B. Paswall AT. Effect of Neem extracts on mycelial growth of the sorghum anthrachnose pathogen, Collectotrichum graminicola Proc. 21st Annual Conference of
Nigerian Society for Plant Protection, 1991. 10-13 March, pp 47.

18. Tijjani A. Gurama AU. Aliyu M. In vitro and In vivo evaluation of some plant extracts for the control of wet rot disease of potato caused by Rhizopus stolonifer. Journal of league of Researchers of Nigeria, 2010. 11(2):45-49.

19. Kareem SO. Akpan I. Ojo OP. Antimicrobial Activities of Calotropis procera on selected pathogenic microorganisms. African J. Biomedical Res. 2008. 11: 105- 110.

20. Rizk MA. Phytotoxic effect of Calotropis procera extract on seedling development and rhizosphere microflora of tomato plants in soil infested with Fusarium oxysporum f. sp. lycopersici. World Appl. Sci. J. 2008. 3(3):391-397.

21. Venkatesan S. Subramanian SP. Evaluation of antifungal activity of Calotropis gigantea latex extract: An in vitro study. Internat. J. Pharmaceut. Sci. and Res. 2010. 1 (9):88-96.

22. Moubasher AH. Elnaghy MA. Megala SE. Fungi isolated from sclerotia of Sclerotium cepivorum and from soil and their effects upon the pathogen. Plant and Soil, 1970.33: 305-312.

23. Singh UP. Pandey VN. Wagner KG. Singh KP. Antifungal activity of ajoene, a constituent of garlic (Allium sativum).Can. J. Bot.1990. 68: 1354-1356.

24. Hasan MM. Chowdhury SP. Alam S. Hossain B. Alam MS. Antifungal effects of plant extracts on seed-borne fungi of wheat seed regarding seed germination, Seedling health and vigour index. Pak. J. Biol. Sci. 2005. 8: 1284-1289.

25. Tagoe DNA. Nayar HD. Akpaka RA comparison of antifungal properties of onion (Allium cepa), Ginger (Zingiber officinale) and Garlic (Allium sativum) against Aspergillus flavus, Aspergillus niger and Cladosporium herbarum. Res. J. Med. Plant, 2011. 5: 281-287.

26. Daya R. Ram D. Fungitoxic properties of some plant extracts against Alternaria brassicae. Ann. Agri. Biol. Res. 1997. 2:25-26.

27. Mondall NK. Mojumdar A. Chatterje SK. Banerjee A. Datta JK. Gupta S. Antifungal activities and chemical characterization of neem leaf extracts on the growth of some selected fungal species in vitro culture medium. Journal of Applied Sciences and Environmental Management, 2009. 13(1): 49-53.

28. Saheb SL. More SM. Junne SB. Wadje SS. The antifungal activity of five Terminalia species checked by paper disc method. International Journal of Pharma Research and Development. 2011.3(2):36-40.

29. Senguttuvan J. Paulsamy S. Krishnamoorthy K. In vitro antifungal activity of leaf and root extracts of the medicinal plant, Hypochaeris radicata L. International Journal of Pharmacy and Pharmaceutical Sciences, 2013. 5(3): 758-761.

30. Mangang HC. Chhetry GKN. Antifungal properties of certain plant extracts against Rhizoctonia solani causing root rot of French bean in organic soil of Manipur. International Journal of Scientific and Research Publications, 2012. 2 (5): 1-4.

31. Tijjani A. Adebitan SA. Gurama AU. Aliyu M. Haruna SG. Mohammad GU. Musab I. In vitro and in vivo efficacy of some plant extracts for the control of tomato fruit rot caused by Aspergillus flavus. International Journal of Scientific and Research Publications, 2014. 4(4):1-5.

32. Parveen S. Wani AH. Ganie AA. Pala SA. Mir RA. Antifungal activity of some plant extracts on some pathogenic fungi. Archives of Phytopathology and Plant Protection, 2014. 47:279284, Doi: 10.1080/03235408.2013.808857.

33. Koka JA. Wani AH. Bhat MY. Parveen S. Antifungal Activity of Ethanolic and Aqueous Leaf Extracts of Taraxicum officinale and Mentha arvensis on the growth of some selected fungal species under in vitro Conditions, Int. J. Pure App. Biosci., 2017. 5 (5):1170-1176

34. Koka JA. Wani AH. Bhat MY. Wani TA. Parveen S. Antimycotic activity of ethanolic and aqueous leaf extracts of Ajuga bracteosa Wall. Ex Benth. (Lamiale: Lamiaceae) and Iris kashmiriana Baker (Asparagales: Iridaceae) against some vegetable rot fungi. Brazilian Journal of Biological Sciences, 2018. 5 (9):75-84

35. Satpute SB. Vanmare DJ. In vitro antifungal activity of Tamarindus indica L. extract against pathogenic fungi. International Journal of Botany Studies, 2017.2(3): 25-28.

36. Jantasorn A. Moungsrimuangdee B. Dethoup T. In vitro antifungal activity evaluation of five plant extracts against five plant pathogenic fungi causing rice and economic crop diseases. Journal of Biopesticides, 2016. 9(1): 01-07. 